\title{
KEPADATAN BAKTERI PADA MEDIA PEMELIHARAAN IKAN GURAMI (Osphronemus gouramy) DENGAN SISTEM BIOFLOK DAN PENAMBAHAN PROTEIN YANG BERBEDA
}

\author{
Arif Wijaya Rahman ${ }^{1}$, Muarif ${ }^{2}$, Mulyana ${ }^{2}$ \\ ${ }^{1}$ Mahasiswa S1 Jurusan Akuakultur, Fakultas Pertanian, Universitas Djuanda Bogor \\ ${ }^{2}$ Staf Pengajar Jurusan Akuakultur Fakultas Pertanian, Universitas Djuanda Bogor \\ Jl. Tol Ciawi 1, Kotak Pos 35 Bogor 16720 \\ Email: arif.wijaya.rahman@unida.ac.id
}

\begin{abstract}
The research is aimed to know and analyze the density of bacteria in the biofloc system on the Maintenance of Giant Gouramy. This research use giant gouramy fry with length of 5-7 cm. The experimental design was used is completely randomized design with 2 treatments and 6 replications. The treatments are Treatment A (mollase addition with $\mathrm{C} / \mathrm{N}$ ratio of $12+$ the feed protein of $17 \%$ ) and treatment $\mathrm{B}$ (the feed protein of $30 \%$, without mollase addition). Fish reared for 45 days and and fed commercial pellet twice a day i.e at 8 am and 4 pm. The density of bacteria and water quality has been evaluated. The results of research showed that the addition of biofloc is not significantly different $(\mathrm{P}>0.05)$ between treatments against the density of bacteri in the biofloc system. Water quality (temperature, $\mathrm{pH}$, and dissolved oxygen) in this research is still in the tolerancelimit of fish farming. The results of bacteria identification that dominant in the bioloc system are Bacillus sp., Enterococcus sp., Acinetobacter sp. and Micrococcus sp., while bacteria are dominant in the treatment without bofloc are Micrococcus sp., Enterococcus sp., Acinetobacter sp. and Bacillus sp.
\end{abstract}

Keywords: biofloc, giant gouramy, density of bacteria, water quality

\begin{abstract}
ABSTRAK
Penelitian ini bertujuan untuk menentukan dan menganalisis kepadatan bakteri di dalam sistem bioflok pada pemeliharaan ikan Gurami. Ikan uji yang digunakan adalah ikan Gurami yang berukuran 5-7 cm. Penelitian ini menggunakan Rancangan Acak Lengkap dengan 2 perlakuan dan 6 ulangan dengan perlakuan A (Penambahan molase $\mathrm{C} / \mathrm{N}$ rasio 12 dan pakan berprotein 17\%) dan $\mathrm{B}$ (tanpa pemberian molase dan pakan berprotein 30\%). Ikan dipelihara selama 45 hari dan diberi pakan pelet komersil 2 kali sehari setiap jam 08.00 dan jam 16.00 WIB. Parameter yang diamati meliputi kepadatan bakteri dan kualitas air. Hasil penelitian menunjukan bahwa penambahan bioflok tidak memberikan pengaruh yang nyata antar perlakuan $(\mathrm{P}>0,05)$ terhadap kepadatan bakteri dalam sistem bioflok. Kualitas air (suhu, $\mathrm{pH}$ dan oksigen terlarut) selama penelitian masih dalam batas toleransi budidaya ikan. Hasil identifikasi bakteri yang dominan dalam perlakuan bioflok adalah Bacillus sp., Enterococcus sp., Acinetobacter sp. dan Micrococcus sp., sedangkan bakteri dominan pada perlakuan tanpa bioflok adalah Micrococcus sp., Enterococcus sp., Acinetobacter sp. dan Bacillus sp.
\end{abstract}

Kata kunci: bioflok, gurami, kepadatan bakteri, kualitas air

Arif Wijaya Rahman, Muarif, Mulyana. 2020. Kepadatan Bakteri pada Media Pemeliharaan Ikan Gurami (Osphronemus gouramy) dengan Sistem Bioflok dan Penambahan Protein yang Berbeda. Jurnal Mina Sains 6(1): 33-39.

\section{PENDAHULUAN}

Ikan Gurami (Osphronemus gouramy) merupakan salah satu ikan yang memiliki nilai ekonomis yang tinggi. Setiap tahunnya permintaan terhadap ikan gurami ini terus mengalami peningkatan. Hal tersebut dapat dilihat dari data produksi ikan gurami di Indonesia pada tahun 2012 sebesar 84.681 ton dan meningkat pada tahun 2013 sebesar 94.605 ton, kemudian pada tahun 2014 sebesar 118.776 ton (KKP, 2015). Walaupun demikian permintaan pasar masih belum bisa terpenuhi dengan baik. Belum terpenuhinya permintaan pasar ikan gurami disebabkan oleh beberapa faktor yang diantaranya yaitu pertumbuhan 
gurami yang lambat dibandingkan dengan ikan tawar lainnya.

Salah satu upaya perbaikan teknik budidaya dan perbaikan nutrisi yaitu dengan menggunakan teknologi bioflok. Karena teknologi bioflok dilakukan dengan menambahkan karbohidrat organik kedalam media pemeliharaan untuk meningkatkan $\mathrm{C} / \mathrm{N}$ rasio dan merangsang pertumbuhan bakteri heterotrof yang dapat mengubah nitrogen anorganik menjadi biomass bakteri (Crab et al. 2007). Hubungan $\mathrm{C} / \mathrm{N}$ rasio dengan mekanisme kerja bakteri yaitu bakteri memperoleh makanan melalui substrat karbon dan nitrogen dengan perbandingan tertentu. Bakteri heterotrof diketahui dapat merubah buangan amonia-nitrogen budidaya menjadi biomass bakteri yang potensial sebagai sumber pakan untuk ikan (Toi et al. 2013).

Penelitian tentang kepadatan bakteri dengan teknologi bioflok pada sistem pemeliharaan ikan Gurami perlu dilakukan sebagai upaya untuk menghindari dampak lingkungan dari pembuangan sisa limbah yang tinggi dan untuk mengurangi penggunaan pakan buatan pada ikan serta sebagai pakan tambahan untuk ikan.

Molase merupakan buangan akhir proses pengolahan gula setelah mengalami kristalisasi berulang dan berwarna coklat kehitaman serta berbentuk cairan kental (Paturau, 1982). Molase telah dimanfaatkan secara luas sebagai sumber karbon untuk proses denitrifikasi, fermentasi anaerob, konversi limbah hingga kegiatan akuakultur (Schneider et al. 2006). Bioflok mengandung $39-48 \%$ protein, $12-24 \%$ lemak, 3-4\% serat kasar dan 25-28\% abu (Widanarni et al. 2012). Kandungan tersebut dapat digunakan sebagai alternatif sumber pakan alami berprotein tinggi bagi ikan maupun udang.

\section{METODE PENELITIAN}

\section{Waktu dan Tempat Penelitian}

Percobaan ini dilaksanakan pada bulan April sampai dengan bulan Agustus 2018, bertempat di Laboratorium Perikanan, Universitas Djuanda Bogor dan Laboratorium Kesehatan Ikan IPB.

\section{Rancangan Percobaan}

Rancangan percobaan yang dilakukan pada penelitian ini adalah Rancangan Acak Lengkap (RAL) dengan 2 perlakuan 6 kali ulangan.

Perlakuan yang diberikan adalah:

Perlakuan A: Penambahan molase $\mathrm{C} / \mathrm{N}$ Ratio 12 dan pakan berprotein $17 \%$.

Perlakuan B: Tanpa pemberian molase dan pakan berprotein $30 \%$.

\section{Prosedur Percobaan}

a) Wadah yang digunakan adalah pemeliharaan ikan adalah bak silinder berdiameter satu meter dan tinggi satu meter berjumlah 12 bak. Wadah diisi air dengan ketinggian $70 \mathrm{~cm}$ dan diisi ikan sebanyak 50 ekor/wadah. Ikan yang digunakan adalah ikan Gurami berukuran 5-7 $\mathrm{cm}$. Pemeliharaan ikan dilakukan selama 45 hari. Pemberian pakan dilakukan 2 kali sehari yaitu pada pukul 08.00 dan 16.00 WIB secara at satiation. Selama pemeliharaan, media pemeliharaan A1-A6 diberi molase $\mathrm{C} / \mathrm{N}$ ratio 12. Pemberian molase pada media pemeliharaan A1-A6 dilakukan satu kali sehari satu jam setelah pemberian pakan terakhir. Selama penelitian dilakukan pergantian air dalam perlakuan B1-B6 tanpa pemberian molase.

b) Penambahan Karbon/Molase. Sumber karbon yang digunakan adalah molase. Efisiensi konversi mikroba diasumsikan $40-60 \%$, sehingga jumlah nitrogen yang terbuang dalam perairan dapat dihitung berdasarkan jumlah pakan, kandungan $\% \mathrm{~N}$ dalam pakan serta $\% \mathrm{~N}$ yang diekskresi. Penambahan molase pada 
media budidaya dilakukan dengan mengadaptasi perhitungan yang dilakukan oleh Avnimelech (1999), yaitu:

$\Delta \mathrm{CH}=\underline{(\text { Pakan } \mathrm{x} \% \mathrm{~N} \text { Pakan } \mathrm{x} \% \mathrm{~N} \text { Ekskresi }) \times[\mathrm{C} / \mathrm{N}] \text { mic }}$ $\% \mathbf{C X E}$

$\Delta \mathrm{CH}$ : Jumlah karbon yang harus ditambahkan

$\% \mathrm{~N}$ : Kandungan Nitrogen yang dibuang oleh ikan

$[\mathrm{C} / \mathrm{N}] \mathrm{mic}: \mathrm{C} / \mathrm{N}$ rasio bakteri

$\% \mathrm{C}$ : Kandungan karbon dalam pakan dan sumber karbon tambahan

E : Efisiensi konversi mikroba

Dilakukan uji proksimat pakan terlebih dahulu dan uji kandungan $\mathrm{C}$ organik molase.

Tabel 1 Alat dan Metode yang Digunakan untuk Mengukur Kualitas Air

\begin{tabular}{cccc}
\hline Parameter & Satuan & Metode/Alat & Waktu Pengukuran \\
\hline Suhu & ${ }^{\circ} \mathrm{C}$ & Termometer & 1 hari $/ 3$ kali \\
$\mathrm{pH}$ & - & pH-meter & 1 hari $/ 3$ kali \\
DO & $\mathrm{mg} / \mathrm{L}$ & DO-meter & 1 hari $/ 3$ kali \\
\hline
\end{tabular}

\section{Kualitas Air}

Kualitas air sangat penting dalam menunjang keberhasilan dalam kegiatan budidaya. Adapun beberapa parameter kualitas air yang diukur dalam penelitian ini dapat dilihat pada Tabel 1.

\section{Analisis Data}

Data yang diperoleh kemudian dianalisis menggunakan analisis ragam untuk melihat pengaruh dari perlakuan yang diberikan. Bila terdapat pengaruh nyata, dilakukan uji lanjut menggunakan uji Beda Nyata Terkecil menurut Steel dan Torrie (1981).

\section{HASIL DAN PEMBAHASAN}

\section{Hasil \\ Kepadatan Bakteri dan Jenis Bakteri}

Data kepadatan bakteri total selama 45 hari pemeliharaan yang diamati selama 15 hari sekali disajikan pada Tabel 2, 3 dan 4.

\section{Parameter yang Diamati Kepadatan Bakteri}

Perhitungan kepadatan bakteri dilakukan setiap 15 hari sekali dengan metode hitung cawan yaitu dengan melakukan pengenceran berseri $10^{-4}$ CFU/mL-1 sampai $10^{-5} \mathrm{CFU} / \mathrm{mL}-1$, kultur di inkubasi pada suhu $28-30^{\circ} \mathrm{C}$ selama 24 jam sampai 48 jam. Bakteri yang tumbuh ditentukan dalam Colony Forming Unit (CFU) dan dihitung dengan rumus sebagai berikut:

$$
\begin{gathered}
\text { Total Bakteri }=\sum \times \frac{1}{F P} \times \frac{1}{m l \text { sampel }} \\
\text { FP : Faktor Pengenceran }
\end{gathered}
$$


perlakuan B1-B6 mengalami penurunan kepadatan bakteri setiap bertambahnya masa pemeliharaan. Kepadatan bakteri pada perlakuan A cenderung baik hal ini karena adanya penambahan sumber karbon berupa molase yang dapat mendukung pengembangbiakan mikroba dalam air.

Tabel 2 Kepadatan Bakteri pada Pemeliharaan Gurami Selama 15 Hari

\begin{tabular}{ccc}
\hline \multirow{2}{*}{ Ulangan } & \multicolumn{2}{c}{ Perlakuan } \\
\cline { 2 - 3 } & $\mathrm{A}$ & $\mathrm{B}$ \\
\hline 1 & $7,8 \times 10^{4}$ & $3,8 \times 10^{4}$ \\
2 & $6,6 \times 10^{4}$ & $11,8 \times 10^{4}$ \\
3 & $3,8 \times 10^{4}$ & $1,2 \times 10^{4}$ \\
4 & $4,6 \times 10^{4}$ & $8,0 \times 10^{4}$ \\
5 & $2,4 \times 10^{4}$ & $4,0 \times 10^{4}$ \\
6 & $5,4 \times 10^{4}$ & $7,4 \times 10^{4}$ \\
\hline Rata-rata & $5,1 \times 10^{4(\mathrm{a})}$ & $6,0 \times 10^{4(\mathrm{a})}$ \\
\hline
\end{tabular}

Keterangan: Superscript yang tidak berbeda menunjukkan hasil tidak berbeda nyata $(P>0,05)$

Tabel 3 Kepadatan Bakteri pada Pemeliharaan Gurami Selama 30 Hari

\begin{tabular}{ccc}
\hline \multirow{2}{*}{ Ulangan } & \multicolumn{2}{c}{ Perlakuan } \\
\cline { 2 - 3 } & $\mathrm{A}$ & $\mathrm{B}$ \\
\hline 1 & $5,0 \times 10^{4}$ & $1,66 \times 10^{4}$ \\
2 & $5,0 \times 10^{5}$ & $2,2 \times 10^{3}$ \\
3 & $7,0 \times 10^{6}$ & $2,52 \times 10^{4}$ \\
4 & $7,48 \times 10^{5}$ & $6,8 \times 10^{3}$ \\
5 & $8,6 \times 10^{5}$ & $1,04 \times 10^{4}$ \\
6 & $1,16 \times 10^{6}$ & $5,12 \times 10^{4}$ \\
\hline Rata-rata & $6,69 \times 10^{5(\mathrm{a})}$ & $1,87 \times 10^{4(\mathrm{a})}$
\end{tabular}

Keterangan: Superscript yang tidak berbeda menunjukan hasil tidak berbeda nyata $(\mathrm{P}<0,05)$

Tabel 4 Kepadatan Bakteri pada Pemeliharaan Gurami Selama 45 Hari

\begin{tabular}{ccc}
\hline \multirow{2}{*}{ Ulangan } & \multicolumn{2}{c}{ Perlakuan } \\
\cline { 2 - 3 } & $\mathrm{A}$ & $\mathrm{B}$ \\
\hline 1 & $1,68 \times 10^{5}$ & $1,44 \times 10^{4}$ \\
2 & $4,68 \times 10^{5}$ & $2,40 \times 10^{3}$ \\
3 & $5,60 \times 10^{5}$ & $3,20 \times 10^{4}$ \\
4 & $2,84 \times 10^{5}$ & $2,92 \times 10^{4}$ \\
5 & $9,6 \times 10^{4}$ & $7,6 \times 10^{3}$ \\
6 & $2,92 \times 10^{5}$ & $6,8 \times 10^{3}$ \\
\hline Rata-rata & $3,11 \times 10^{5(\mathrm{a})}$ & $1,54 \times 10^{4(\mathrm{~b})}$
\end{tabular}

Keterangan: Superscript yang berbeda menunjukkan hasil berbeda nyata $(\mathrm{P}<0,05)$

Sesuai dengan pendapat Ebeling et al. (2006) bahwa, bakteri heterotrof dapat ditingkatkan melalui peningkatan $\mathrm{C} / \mathrm{N}$ rasio dengan menambahkan sumber karbon organik secara kontinu seperti molase, tepung terigu dan tepung tapioka. Beberapa jenis ikan dan udang pada budidaya intensif dapat memanfaatkan bioflok sebagai pakan yang mengandung protein tinggi (Avnimelech, 2007).

Kepadatan bakteri pada perlakuan B cenderung lebih rendah, itu dikarenakan pertumbuhan bakteri disebabkan dengan adanya sisa bahan organik yang berasal dari 
sisa pakan yang tidak dimakan oleh ikan, feses dan pembuangan metabolisme lain dan tidak adanya penambahan sumber karbon organik ke dalam media. Kepadatan bakteri bergantung kepada ketersediaan nutrient dalam air (Ekasari, 2008).

Tabel 5 Jenis Bakteri pada Awal, Tengah dan Akhir Pemeliharaan

\begin{tabular}{clll}
\hline No. & \multicolumn{1}{c}{ Awal } & \multicolumn{1}{c}{ Tengah } & \multicolumn{1}{c}{ Akhir } \\
\hline 1. & Kurthia $\mathrm{sp}$. & Acinetobacter $\mathrm{sp}$. & Bacillus $\mathrm{sp}$. \\
2. & Enterobacteria $\mathrm{sp}$. & Enterococcus $\mathrm{sp}$. & Enterococcus $\mathrm{sp}$. \\
3. & Flavobacterium $\mathrm{sp}$. & Micrococcus $\mathrm{sp}$. & Micrococcus $\mathrm{sp}$. \\
4. & Enterococcus $\mathrm{sp}$. & Bacillus $\mathrm{sp}$. & Acinetobacter $\mathrm{sp}$. \\
5. & Bacillus $\mathrm{sp}$. & Enterobacteria $\mathrm{sp}$. & Aerococcus $\mathrm{sp}$. \\
6. & Alcaligenes $\mathrm{sp}$. & Campylobacterium $\mathrm{sp}$. & Aeromonas $\mathrm{sp}$. \\
7. & Pseudomonas $\mathrm{sp}$. & Staphylococcus $\mathrm{sp}$ & Plesimonas $\mathrm{sp}$. \\
8. & Micrococcus $\mathrm{sp}$. & Camphylobacter $\mathrm{sp}$. & Veilonella $\mathrm{sp}$. \\
9. & Clostridium $\mathrm{sp}$. & & Clostridium $\mathrm{sp}$. \\
10. & Listeria $\mathrm{sp}$. & & \\
\hline
\end{tabular}

Identifikasi bakteri sangat penting dilakukan untuk mengetahui bakteri dominan di dalam bioflok baik itu heterotrof maupun autotrof. Hasil identifikasi bakteri dalam perlakuan A yang dominan yaitu Bacillus sp., Enterococcus sp., Acinetobacter sp. dan Micrococcus sp. Lalu di perlakuan B bakteri yang dominan yaitu Micrococcus sp., Enterobacter sp., Acinetobacter sp. dan Bacillus sp.

Jenis bakteri yang dominan dari perlakuan A dan B adalah Bacillus sp, Micrococcus sp. dan Acinetobacter sp. Beberapa hasil penelitian telah dilaporkan tentang jenis jenis bakteri yang mampu menghasilkan senyawa bioflokulan yang berperan penting dalam pembentukan bioflok diantaranya adalah: Rhodococcus erytthropolis, Flavobacterium sp., Zoogloea MP6, Zoogloea ramigera, Pseudomonas C-120, Bacillus sp., Enterobacter sp. dan Nocardia amarae YK1 (Salehizadeh dan Shojaosadati, 2001). Kedua kelompok mikroba ini mampu menghasilkan senyawa partikel eksopolimer yang berperan dalam pembentukan suatu bioflok pada suatu perairan.

Tabel 6 Kualitas Air Media Pemeliharaan Ikan Gurami Selama Penelitian

\begin{tabular}{lcc}
\hline \multirow{2}{*}{ Parameter } & \multicolumn{2}{c}{ Perlakuan } \\
\cline { 2 - 3 } & Bioflok & Tanpa Bioflok \\
\hline \multirow{2}{*}{ Suhu $\left({ }^{\circ} \mathrm{C}\right)$} & $23,6-$ & $23,7-27,9$ \\
pH & 28,6 & $6,6-8,7$ \\
DO $(\mathrm{ppm})$ & $6,3-8,7$ & $6,6-8,8$ \\
\hline
\end{tabular}

Menurut Sterrit dan Lester (1998), bakteri Acinetobacter sp., Corynobacter sp. dan Pseudomonas sp. Merupakan genus yang sering ditemukan didalam flok. Fry (1987) melaporkan bahwa 90\% - 95\% dari bakteri dalam kolam oksidasi adalah
Pseudomonas sp., Flavobacterium sp. dan Achromobacter sp. Bakteri ini berperan sebagai bakteri denitrifikasi dalam teknologi budidaya bioflok (Nurhayati, 2010). 


\section{Kualitas Air}

Kualitas air berperan sangat penting sebagai media hidup bagi ikan, maka dalam budidaya perairan, kualitas air atau media hidup bagi ikan mutlak diperhatikan demi menjaga kehidupan yang sesuai bagi ikan budidaya, pada penelitian ini kualitas air dalam perlakuan A (bioflok) dan B (tanpa bioflok) relatif baik, meskipun terjadi perbedaan suhu pada perlakuan B disebabkan adanya pergantian air.

Data suhu (Tabel 5) selama penelitian pada perlakuan A berkisar antara 23,6-28, $6^{\circ} \mathrm{C}$ dan perlakuan B berkisar antara 23,7-27, $9^{\circ} \mathrm{C}$. Menurut Cholik (1991) suhu merupakan salah satu faktor penting dalam kehidupan ikan terutama dalam proses kimia dan biologi, ikan akan tumbuh dengan baik pada suhu $25^{\circ} \mathrm{C}-32^{\circ} \mathrm{C}$. Perubahan suhu yang mendadak dapat menyebabkan ikan stress dan kemudian mati.

Derajat keasaman $(\mathrm{pH})$ merupakan suatu ukuran konsentrasi ion $\mathrm{H}$, secara alamiah perairan dipengaruhi oleh konsentrasi $\mathrm{CO}_{2}$ dan senyawa yang bersifat asam. Pengukuran $\mathrm{pH}$ selama penelitian pada perlakuan A berkisar 6,3-8,7 dan perlakuan B berkisar 6,6-8,7. Kisaran $\mathrm{pH}$ yang dapat menunjang pertumbuhan ikan adalah 6,5-9,0 (Boyd, 1982), pH merupakan salah satu faktor lingkungan yang berpengaruh terhadap pertumbuhan dan aktivitas bakteri pengoksidasi ammonia (Esoy et al. 1998).

Bakteri nitrifikasi (bakteri pengoksidasi ammonia) lebih menyukai lingkungan yang basa dengan tingkat $\mathrm{pH}$ optimal untuk pertumbuhan bakteri berkisar antara 7,5-8,5 (Ambarsari, 1999). Nilai pH optimum bagi pertumbuhan bakteri heterotrofik adalah sekitar 6-7 (Irianto dan Hendrati, 2003).

Data oksigen terlarut (DO) selama penelitian pada perlakuan A berkisar 6,28,6 ppm dan perlakuan B berkisar 6,6-8,8 ppm. Rentang DO optimal yaitu $\geq 5 \mathrm{ppm}$ dan rentang tingkat DO untuk pemeliharaan intensif yaitu 5-8 ppm (Boyd, 1982). Batas toleransi kadar oksigen terlarut secara umum untuk budidaya tambak adalah 3-10 ppm, sedangkan nilai optimal untuk budidaya di tambak berkisar antara 4-7 ppm (Poernomo, 1990).

\section{KESIMPULAN DAN SARAN}

\section{Kesimpulan}

Ikan Gurami yang dipelihara dengan sistem bioflok dan tanpa sistem bioflok dengan persentase protein yang berbeda menghasilkan kepadatan bakteri sebagai berikut: 15 hari pemeliharaan: $2.4 \times 10^{4}$ $7.8 \times 10^{4}$ (perlakuan bioflok) $1.2 \times 10^{4}$ $11.8 \times 10^{4}$ (perlakuan tanpa bioflok) 30 hari pemeliharaan: $1.16 \times 10^{6}-8.6 \times 10^{5}$ (perlakuan bioflok) $1.04 \times 10^{4}-6.8 \times 10^{3}$ (perlakuan tanpa bioflok) 45 hari pemeliharaan: $1.68 \times 10^{5}$ $9.6 \times 10^{5}$ (perlakuan bioflok) $1.44 \times 10^{4}$ $7.6 \times 10^{3}$ (perlakuan tanpa bioflok) menunjukkan hasil yang tidak berbeda nyata antar perlakuan $(\mathrm{P}>0,05)$.

\section{Saran}

Melakukan penelitian lanjutan dengan $\mathrm{C} / \mathrm{N}$ rasio yang berbeda untuk mengetahui kepadatan bakteri yang terbaik.

\section{DAFTAR PUSTAKA}

Ambarsari, H. 1999. Karakteristik dan Peran Bakteri Penitrifikasi dalam Usaha Minimalisasi Amonia yang Terakumulasi di Dalam Sistem Akuakultur. Jurnal Sains dan Teknologi Indonesia 1 (2): 43-52.

Avnimelech Y. 1999. Carbon/Nitrogen ratio as control element in aquaculture systems. Aquaculture 176: 227 - 235. Avnimelech Y. 2007. Feeding with microbial flocs by tilapia in minimal discharge bio-flocs technology ponds. Aquaculture 264: 140-147.

Crab R, Avnimelech Y, Defoirdt T, Bossier P, Verstraete W. 2007. Nitrogen Removal Techniques In Aquaculture for a Sustainable Production. Aquaculture, 270: 1-14. 
Cholik. 1991. Pengelolaan Kualitas Air Kolam Ikan. Terjemahan. Jakarta: Direktorat Jendral Perikanan.

Ebeling J M, Timmons M B, Bisogni, J J. 2006. Engineering analysis of the stoichiometry of photoautotrophic, autotrophic and heterotrophic removal of ammonia-nitrogen in aquaculture sistems. Aquaculture 257, 346-358.

Ekasari J. 2008. Bioflocs Technology: The Effect Of Different Carbon Source, Salinity And The Addition Of Probiotics On The Primary Nutritional Value of The Bioflocs [Tesis]. Gent: Faculty Of Bioscience Engineering. Ghent University. [FAO] Food and Agricultural Organization. 2007. The State of World Fisheries.

Esoy, A., H. Odegaard and G. Bentzen. 1998. The Effect of Sulphide and Organic Matter on The Nitrification Activity In Biofilm Procces. Water Science Technology 37 (1): 115-122.

Fry H.J.H. 1987. Prevalence of Overuse (injury) Syndrome in Australian Music Schools. British Journal of Industrial Medicine: Victoria, Australia.

Irianto A dan P. M. Hendrati. 2003. Keragaman Hayati Bakteri Heterotrofik Aerobik Perairan Pantai Baron, Gunung Kidul, Yogyakarta. Fakultas Biologi Universitas Jendral Soedirman Purwokerto. BIODERSITAS.

KKP. 2015. Rencanan Strategis Kementrian Perikanan dan Kelautan 2010-2014. Jakarta : Kementrian Kelautan dan Perikanan.

Nurhayati. 2010. Manajemen Proyek. Graha Ilmu: Jogjakarta.

Paturau J. 1982. By products of the Cane Sugar Industry, Second edition. Elsevier. Amsterdam: Elsevier.

Poernomo, A.1990. Faktor Lingkungan Dominan Pada Budidaya Tambak
Udang Intensif. Yayasan Obor Indonesia. Jakarta.

Salehizadeh, H., dan Shojaosadati, S.A., 2001. Extracellular biopolymeric flocculants Recent trends and biotechnological importance. Journal of Biotechnology Advance, 19: 371385.

Schneider D P E J, Steig, T van Ommen. 2006, High-resolution ice core stable isotopic records from Antarctica: Towards interannual climate reconstruction, Ann. Glaciol., 41, 6370.

Steel Rober G.D dan Torrie James H. (1981). Prinsip dan Prosedur Statistika: Suatu Pendekatan Biometrik. Gramedia, Jakarta.

Sterritt R. M dan Lester J. N, 1988. Microbiology for Environmental and Public Health Engineers. E \& F. N. Spon Ltd : London.

Toi HT, Boeckx P, Sorgeloos P, Bossier P, Stappen GV. 2013. Bacteria contribute to Artemia nutrition in algae-limited conditions: A laboratory study. Aquaculture, 388-391: 1-7.

Widanarni, Ekasari J, Maryam S. 2012. Evaluation of biofloc technology application on water quality and production performance of red tilapia Oreochromis sp. cultured at different stocking densities. Hayati Journal of Biosciences, 19(2): 73-80.

Widanarni, Wahjuningrum D, Puspita F. 2012. Aplikasi Bakteri Probiotik Melalui Pakan Buatan untuk Meningkatkan Kinerja Pertumbuhan Udang Windu Penaeus monodon. Jurnal Sains Terapan 2(1) : 32-49. 